\title{
IMPROVING STUDENTS' THINKING ABILITY IN PHYSICS USING INTERACTIVE MULTIMEDIA BASED PROBLEM SOLVING
}

\author{
Sondang R. Manurung*, Deo Demonta Panggabean \\ Universitas Negeri Medan, Indonesia \\ *e-mail: sondangmanurung@unimed.ac.id
}

\begin{abstract}
Interactive multimedia based learning containing problem solving may have been researched, however there are stigma that learning how to do problem solving conventionally particularly for colleague students is still favorable. The purpose of this paper is to evaluate factors affect the student learning outcomes. The independent variable is a teaching method in the form of interactive multimedia based on problem solving (IMM-PS) and the dependent variable is students' thinking ability in physics. Specifically, this study aims to analyze the problem solving abilities of students in physics education programs after they have been exposed to interactive multimedia based problem solving methods. The research type is quasi-experiment. The sample were second year physics education students who studying wave electric magnetic subjects, as many as seventy students. The test of science process skills in the form of formal descriptions as well as reasoning tests in the form of descriptions were used as instruments for this study. The results show that the problem solving ability of students who study physics using interactive multimedia based problem solving is better than students who learn through conventional methods.
\end{abstract}

\section{Keywords: thinking ability, physic, interactive multimedia, problem solving}

\section{PENINGKATAN KEMAMPUAN BERPIKIR SISWA DALAM FISIKA MENGGUNAKAN MULTIMEDIA INTERAKTIF BERBASIS PEMECAHAN MASALAH}

\begin{abstract}
Abstrak: Pembelajaran berbasis multimedia interaktif yang memuat pemecahan masalah telah banyak diteliti, namun masih ada stigma bahwa belajar bagaimana memecahkan masalah secara konvensional khususnya untuk mahasiswa masih disenangi. Tujuan dari penelitian ini adalah untuk mengevaluasi faktorfaktor yang mempengaruhi hasil belajar siswa. Variabel bebas adalah metode pengajaran dalam bentuk multi media interaktif berbasis pemecahan masalah (MMI-PM) dan variabel terikatnya adalah kemampuan berpikir siswa dalam fisika. Lebih khusus, penelitian ini bertujuan untuk menganalisis kemampuan pemecahan masalah siswa program pendidikan fisika setelah diberi perlakuan metode pemecahan masalah berbasis multimedia interaktif. Jenis penelitian yang digunakan adalah kuasi eksperimen. Sampelnya adalah mahasiswa tahun kedua pendidikan fisika yang sedang belajar magnet elektrik, sebanyak tujuh puluh mahasiswa. Tes keterampilan proses sains dalam bentuk deskripsi formal serta tes penalaran dalam bentuk deskripsi digunakan sebagai instrumen untuk penelitian ini. Hasil penelitian menunjukkan bahwa kemampuan pemecahan masalah fisika siswa yang diajarkan menggunakan multimedia interaktif berbasis pemecahan masalah lebih baik daripada siswa yang belajar melalui metode konvensional.
\end{abstract}

Kata Kunci: kemampuan berpikir, fisika, multimedia interaktif, pemecahan masalah

\section{INTRODUCTION}

Physics is one of the science that underlies the development of technology, so students need to learn it in the form of general physics (Halliday, Resnick, \& Walker, 2011). As prospective lecturers, students majoring in physics education are expected to have high thinking ability. The improvement of lecturers' competence has not been successfully conducted by the training institute for education practitioners (Lembaga
Pendidikan Tenaga Kependidikan or LPTK or Training Institute for Education Practitioners). A study by Manurung (2014) at one of LPTK in Medan shows that the teaching of physics is still overly teacher-centred. University teachers tend to learn through lectures, questions and answers. The implementation of the general physics course still the validity of existing theories, carried out by strictly following a set of provided procedures, instead of encouraging students to 
develop their thinking through experiment. In addition, it was also found that: (a) methods used in these general physics lectures are downright boring as students are required to listen to their lecturer in long hours; the learning is aimed simply students to the theories; and problems presented tends to be academic (book oriented), (b) students lack of experience to be able to solve problems; problems given are rarely relevant to contextual issues in everyday lives of student, so thus learning becomes less meaningful to students. Those evidents arise from low participation in teaching and learning activities and their relatively low achievement. Furthermore, a number of problems in the teaching of general physics have been identified: (a) the learning process does not present relevant phenomenon, (b) lack of discovery process, (c) lack of learning media, and (d) weak understanding of the concepts. these problems cause difficulties for students to understand the concepts of general physics graphics presented in learning physics.

One of the important factors that influence the low performance of science lecturers is the lack of effective pre-service teacher education (Fhaeizdhyall, Nazamud-Din, Sabbir, \& Ibrahim, 2018). Teachers' quality is a major factor in increasing teaching and learning quality. Thus, there is a vital need to improve professionalism in the field of education (Depdiknas, 2010). A sustainable and effective teacher education to improve teachers' quality is crucial. Equipping with knowledge and hands-on experience in doing physics experiments that involve abstract physics concepts interactive multimedia is relevant because not all experiments can be done directly in laboratory. Most students experience difficulties in solving physics problems neither do they have a deep understanding of the fundamental concepts in the problem. To overcome this situation, we propose a computerassisted learning tool known as the adaptive learning environment for problem solving (ALEPS) based on "Polya stages of problem solving" that consists of 1) understanding; 2) planning; 3) applying, and 4) checking (Bimba, Idris, Mahmud, Abdullah, Abdul-Rahman, \& Bong, 2013). Thinking and problem-solving skills as well as speed in problem solving are only developed through practice and feedback. Testing students on skills they have not had an opportunity to practice is unfair (Heller \& Heller, 2010; Gorghiu, Drăghicescu, Cristea, Petrescu, \& Gorghiu, 2015).

Fenelon \& Breslin (2012) designed a thinking model and laboratory content on the web-based basic physics lecture, and found that long-distance students' as those with direct interaction. And virtual for various concepts of basic algebra-based physics through project phet (physics education technology) are reported by Habibi \& Habibi (2015) to cope with the large number of participants course in universities. Furthermore Habibi \& Habibi (2015); Chetty (2015) stated that computers can be used to support the implementation of practical physics for gathering, presenting, and manipulating data. Kapi, Osman, Ramli, \& Taib (2018) also argue that a number of forms of interaction may be presented through theof computer serving as practices and exercises, tutorials, games, simulation, discovery, and thinking. According to de Sousa, Richter, \& Nel (2017) the utilization of multimedia in learning encourages students to the process of invention (discovery learning process) and can solve ill structured problems (Cunningham, 2009). Kapi et al. (2018) said that interactive multimedia as audio-visual media can show phenomena in physics in a more real manner. A more real visualization strongly supports $\mathrm{c}$ in the learning process. in addition, students get in their learning process. thus, students' skill will increase, which in turn will hopefully encourage the emergence of students' creativity.

Thinking is a complex process and is important in the everyday of learning physics. problem-solving tests focus at the end of result or the middle of the process of learning, rather than on the quality of the procedures and the reasoning that leads to results. Thinking skills developed in general physics present a situation where certain information is given, more often as numerical values for the variables in those situations, so that the value of other variables can be determined. So, problem tends to be welldefined. Meanwhile, life physical problems or those faced by physicist are mostly ill-structured problems, a problem that must be solved through innovative physics (Cunningham, 2009). Lawson (1978) states that the ability to think is a person's ability to solve problems, to think and devise solutions with a logical sequence (sense), 
as well as career and work. Thinking ability make problem solving important to get the work.

Thinking ability shows that a person has formal reasoning. according to Piaget (1964) there are five aspects of the operation of formal reasoning, namely: proportional reasoning, control variables, proportional reasoning, correlational reasoning, and combinatorial reasoning. According to (Arends, 2012), problem solving based learning can improve thinking ability.

Based on the description above, this article will explain the improvement of thinking ability in physiscs through an interactive multimediabased learning problem solving (MMI-PS), because this model can improve thinking ability and skills in solving ill-structured problems (Byun, Kwon, \& Lee, 2014; de Sousa et al., 2017).

\section{METHODS}

The research method adopted in this study is experiment (Fraenkel, Wallen, \& Hyun, 2011) by testing the model in a limited class with pre-test-post-test control group design. This research involves two classes that were treated differently. Each of the two classes was assigned into experimental and control groups. The experimental class taught using the interactive multimedia-based learning containing problem solving (IMM-PS) while the control group taught using conventional learning method. The research sample consist of 35 students per class, i.e. second years physics education students. Second year students get a wave electric magnetic subjects, each number 35 persons per class. We performed two (2) studies. Study 1 is implementation of IMM-PS on experimental group that is consists of 35 students. Study 2 is performing teaching using conventional learning method to control group that is consists of 35 students as well. Both studies follow 6 steps as shown on Figure 1 and 2.

Starting with the provision of pre-tests in both groups, then given treatment that is giving IMM-PS in the experimental group, conventional treatment in the control group. After that the test post is given. In the experimental group the steps were carried out as shown in Figure 1. In the beginning with a briefing for branstorming steps is called is brainstorming activities is briefing activity.

In the learning instruction there are discussion groups, to discuss physics problems. The third step is to solve the problems and problem-solving techniques will be made in the meeting, where group problem-solving involves the spontaneous contribution of ideas by all members of the group, also in order to compile or find a work around. The fourth step is to look at physical phenomena to investigate of physical phenomena by using problem-solving interactive multimedia and discussion. Thinking-laden interactive multimedia helps students investigate physical phenomenon while solving problems in a group. problem based learning (PBL) is a

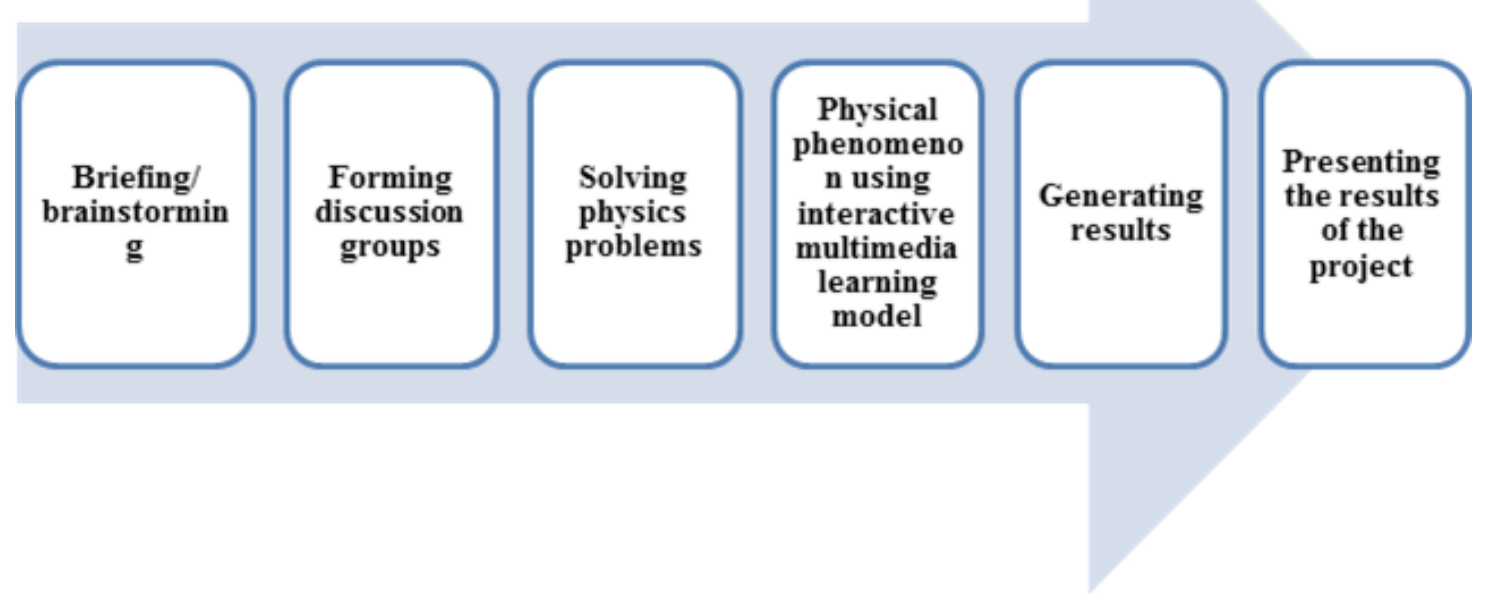

Figure 1. Steps in the Interactive Multimedia Based on Learning Model Containing Problem Solving 
learning approach that uses real-world problems as a context for students to learn critical thinking and problem-solving skills, as well as to acquire mastery of the knowledge and essential concepts of the subject matter (Sudarman, 2007). PBL challenges students to find solutions to existing problems in the real-world through group work. The fifth step is to find the findings of physical symptoms. Finally, the sixth step presented the findings

The research instrument is a thinking ability test is test of logic thinking (TOLT), TOLT consisting of 10 multiple choice questions which instrument validity and reliability have been ensured. This instrument developed by Tobin \& Capie (1981). The value of the validity and reliability of the instrument TOLT is .67 and .80. Instrument translated into the English language (Tobin \& Capie, 1982). The research sample consisted of 35 students per class, i.e. second semester physics education students. The research carried at a LPTK in Medan, as a research and problem solving learning effectivity test site.

Anova is used to find out wheter interactive multimedia-based learning containing problem solving (IMM-PS) can improve students' thinking. Based on the analysis of preliminary study needs, it was found that students and professors of the multimedia program in learning were activated and followed by analyzing interactive multimedia. With a controller that can be operated by user, so thus user can select what is desired for the next process. Examples of interactive multimedia include: multimedia interactive learning games, applications, etc. of multimedia-based learning is shown in Figure 2.

Figure 2 describes the preliminary stage of the study namely the literature review and needs analysis required for the formulation of competency indicators to determine the learning, multimedia and story board designs, features , which finally tested on students and discussed with an expert. Interactive multimedia allows the user to realise potential no longer passive reader, but rather as a co-author, as they determine the sequences of their reading experience potential, will have the ability to rearrange their knowledge with respect to the condition of complex knowledge.

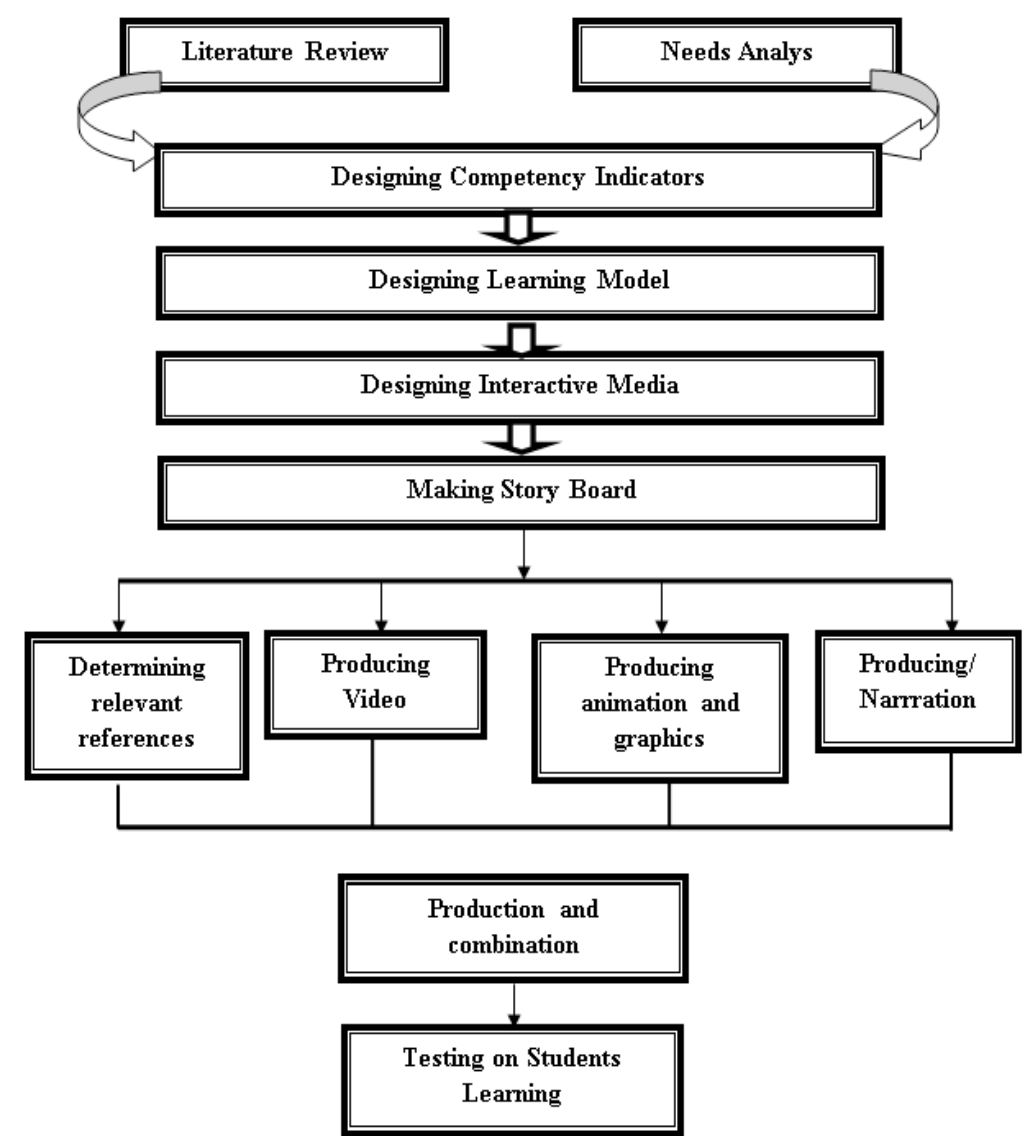

Figure 2. Paradigm of the Based on the Phylosophy 
Examples of interactive multimedia shown on Figure 3. The movement of the pendulum harmonic phenomena is often considered simple, but in fact, since a number of representations: (1) from the object of the phenomenon; (2) representation of measurement, such as the position of the pendulum in a particular cycle of oscillation; (3) representation of the pendulum phenomenon graphic according to time and speed. Designation of pendulum symptoms in interactive multimedia.

Figure 3 shows the process of building knowledge according to the complexity of symptoms that can be done according to user's navigation, the simulation allows user to reconstruct the needs to improve the substantiation and transfer capabilities a complex concept which refers to advanced knowledge obtained (Nickel, 2014). Through research simulation. According to Heller \& Heller (2010) the strategies of problem-based learning consisted of five steps: a) the problem (the focus of the problem), b) the concept in (describe the physics), c) planning solutions (plan the solution), d) out the plan (execute the plan), and e) an evaluation the solution (evaluate the solution).

\section{FINDINGS AND DISCUSSION Findings}

In the beginning of the study, students in both classes were given a pre-test (initial competency test) that aimed to find out whether their thinking ability was on the same level. The results of the experimental class and control class ranged from 0 to 10. Based on the pre-test results of the experimental class, the lowest score was 4 (1 person), while the highest score was 10 (1 person) (Figure 4). The average score was 6.86 and the standard deviation was 1.3. Whereas, in the control class the lowest score was $4(2$ people), and the highest score was 10 (1 person) (Figure 4). The average score was 6.94 and the standard deviation was 1.43 .

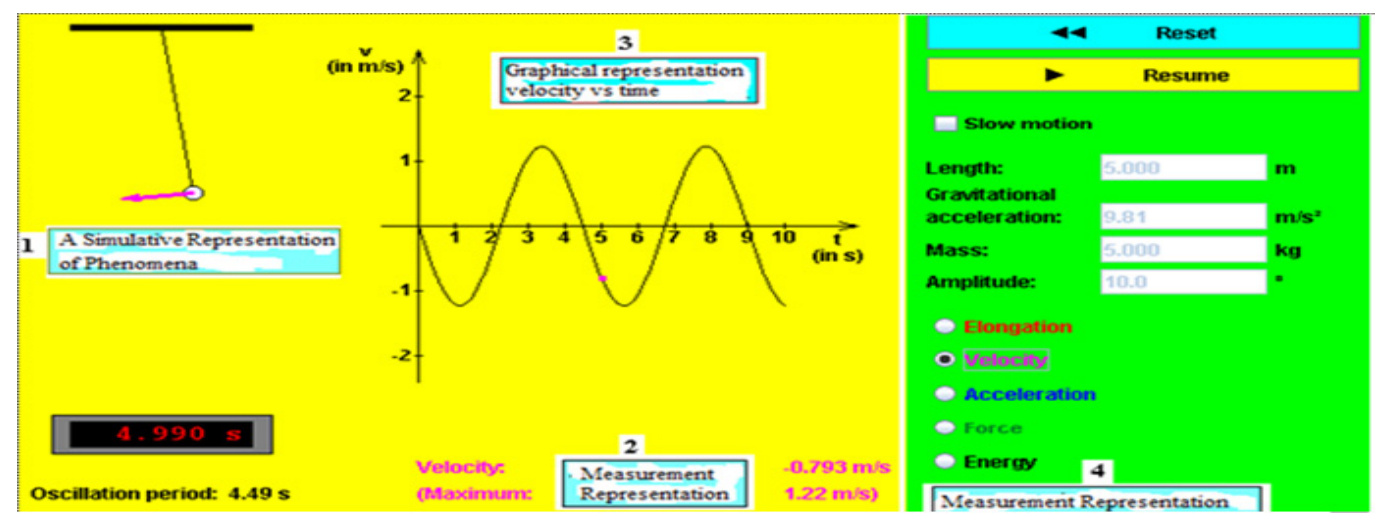

Figure 3. The Pendulum Symptom, According to the Knowledge Representative Constructs Basic Knowledge about Pendulum

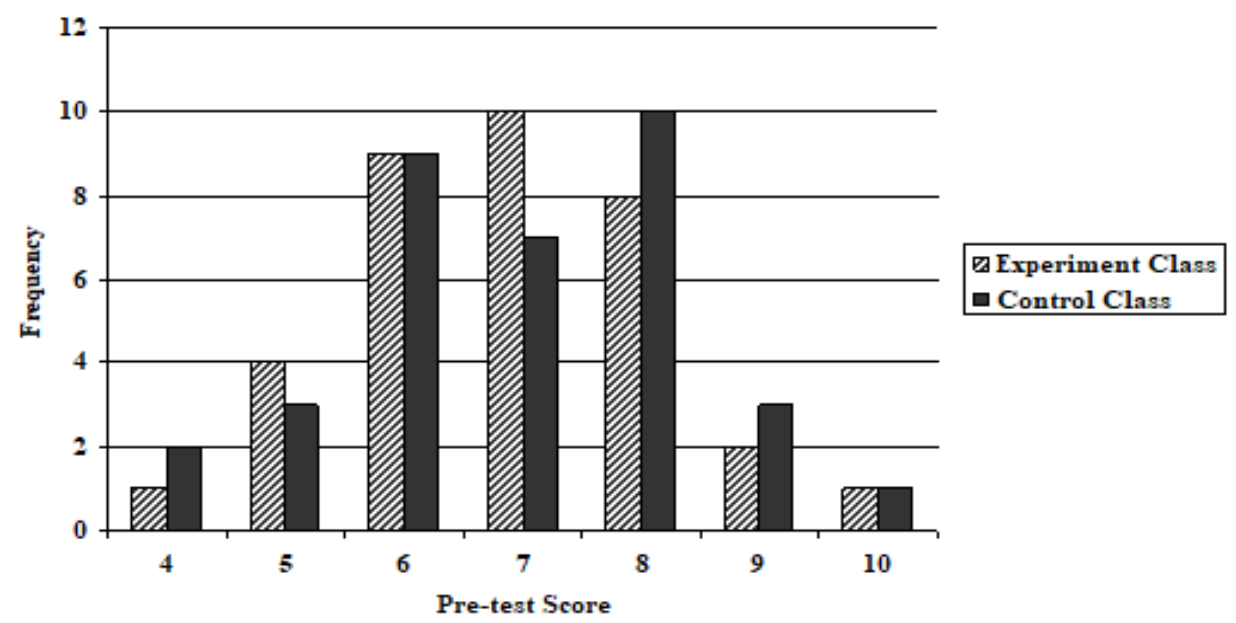

Figure 4. Pretest Scores of the Experiment Classes and Control Classes 
The pre-test scores of the experimental and control classes-were not significantly different ( $p$ $<.05$ ), meaning that both classes the same initial capabilities and acquisition value. Data of pretest and post-test in experiment group is shown in Table 1.

As the post test result, presented in the Figure 5, the lowest score increased from 4 to 6 ( 1 person) in the experimental class (table 2). The number of students who the highest score, 10 , also increased to people (5). In addition, the class score average improved from 6.86 to 8.43 with a standard deviation from 1.31 to 1.04. In the control class, the lowest score 5 (3 people), and the highest score 10 (4 people) with an average of 7.49 and a standard deviation of 1.46. There also a great difference the number of students who achieved a score of 9 (13 students from the experiment class as opposed to only 4 students the control class) (see Table 2).
The statistical analysis (1) indicates that there is a significant difference $(p<.05)$, between the average score of the experiment and control group where the group experiment is influenced experimentation IMM-PS, conventional teaching method, as conducted in the control group, did not result in significant difference between the students' achievement before and after treatment $(p<.05)$ (see Table 3).

\section{Discussion}

Abungu, Okere, \& Wachanga (2014) states that the ability of computer-assisted formal reasoning and learning deals with logical thinking ability of chemistry (chemistry student). The results of this study that using a problemsolving model, especially on dynamic fluid materials, resulted in a very good average scores and moderately increased students' ability to think. Kharida, Rusilowati, \& Pratiknyo (2009)

Table 1. Data of Pre-test Scores and Post-test Score in Experiment Group

\begin{tabular}{|c|c|c|c|c|c|c|c|c|c|c|}
\hline \multirow[b]{2}{*}{ No } & \multicolumn{5}{|c|}{ Pretest Value } & \multicolumn{5}{|c|}{ Posttest Value } \\
\hline & Scores & $F$ & $\bar{x}$ & $S^{2}$ & $S$ & Score & $F$ & $\bar{x}$ & $S^{2}$ & $S$ \\
\hline 1. & 4 & 1 & & & & & & & & \\
\hline 2. & 5 & 4 & & & & 5 & - & & & \\
\hline 3. & 6 & 9 & & & & 6 & 1 & & & \\
\hline 4. & 7 & 10 & 6.86 & 1.71 & 1.31 & 7 & 6 & 8.43 & 1.08 & 1.04 \\
\hline 5. & 8 & 8 & & & & 8 & 10 & & & \\
\hline 6. & 9 & 2 & & & & 9 & 13 & & & \\
\hline 7. & 10 & 1 & & & & 10 & 5 & & & \\
\hline & Total & 35 & & & & & & 35 & & \\
\hline
\end{tabular}

Note: $F=$ Frequency; $\bar{x}=$ Average; $S^{2}=$ Variance; $S=$ Standard Deviation

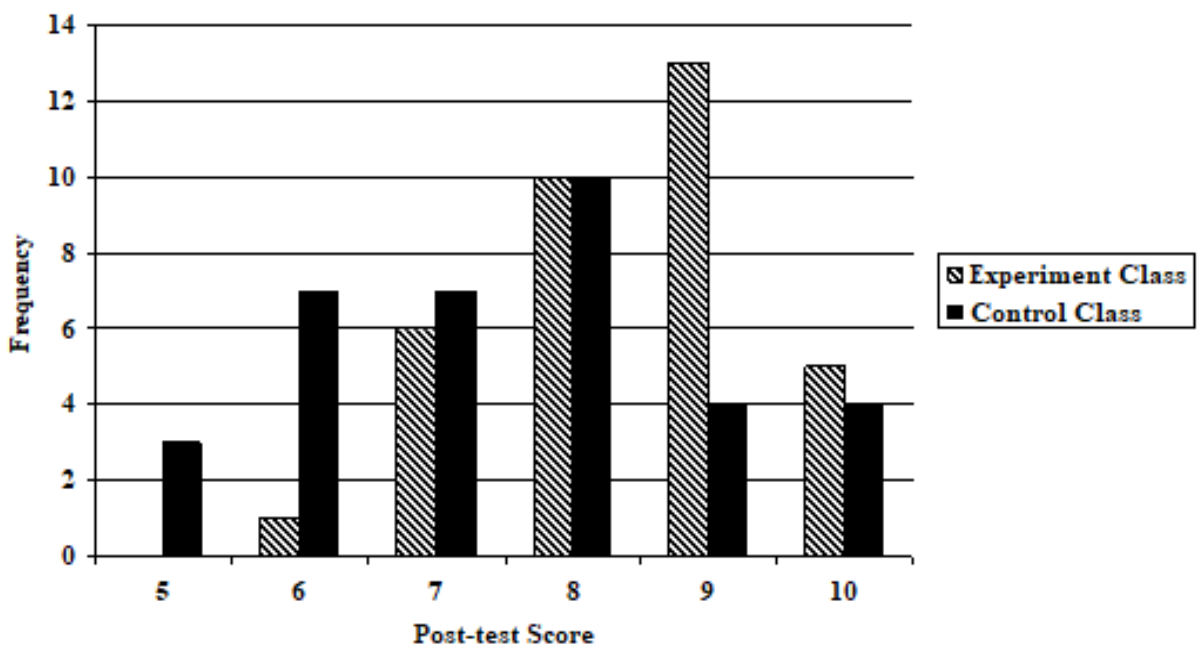

Figure 5. Posttest Scores of the Experiment Classes and Control Classes 
Table 2. Comparison of Score Averages in Pre-test and Post-tests of Thinking Abilities by the Experimental and Control Groups

\begin{tabular}{lcccccc}
\hline Group & $\boldsymbol{N}$ & $\boldsymbol{M}$ & $\boldsymbol{S D}$ & $\boldsymbol{d f}$ & $\boldsymbol{t}_{\text {sum }}$ & $\boldsymbol{t}_{\text {table }}$ \\
\hline Experimental & 35 & 8.43 & 1.04 & 68 & 2.876 & 1.669 \\
Control & 35 & 7.49 & 1.46 & 68 & & \\
\hline
\end{tabular}

Note: Significant at $p<.05$

Table 3. Comparison of Control Group's Average Scores before and after Treatment

\begin{tabular}{lccccc}
\hline Group & $\boldsymbol{N}$ & $\boldsymbol{M}$ & $\boldsymbol{S D}$ & $\boldsymbol{d f}$ & $\boldsymbol{t}_{\text {sum }}$ \\
\hline Control group before treatment & 35 & 6.94 & 1.43 & 68 & $.12^{*}$ \\
Control group after treatment & 35 & 7.49 & 1.46 & 68 & \\
\hline
\end{tabular}

Note: *Not Significant at $p<.05$

states in his research that there is an increase in the average thinking ability of students taught with problem based learning model. According to Arends (2012), a problem based learning approach to learning, in which students work on authentic problems with a view to drawing up their own knowledge, while the teacher as a facilitator then student must be persistent in solving the problems presented, then all the characters of the students will show themselves and students can develop independence and confidence so that the ability to think can be achieved.

Based on this study, the test results average of students from the experiment class increased from 6.86 to 8.43 , while in the control class, it increased from 6.94 to 7.49 . The statistical analysis showed that students from the experiment class attained significantly higher post test average compared to students from the control class $(p<.05)$. In addition, the average $\mathrm{N}$-Gain value of students taught using problem based learning model is .5 or $50 \%$, with a moderate level improvement in logical thinking competence. Meanwhile, the average n-gain value of students taught using the conventional approach is .2 or $20 \%$. This means that the improvement of students' logical thinking ability in the experimental class is greater than in the control class. Thus, we can conclude that student's ability to think logically were enhanced due to the influence of the problembased learning model on kinematic physics education. Similar result was obtained by Islam, Ahmed, Islam, \& Shamsuddin (2014) who stated that the use of multimedia animation as teaching media improved students' thinking process; in which students in experiment class obtained .682 improvement, while students in control class only .326 improvement. It can be inferred from his results, as well as ours, that there exists a difference in logical thinking abilities between the two student classes. This is because learning that uses multimedia encourages students to be actively engaged in the thinking process with regards to the material and linking learning to reallife situations. Thereby, students are motivated to remember and apply the knowledge in everyday life situations. In other words, students are not just passively accepting material from a lecturer but are actively solving problems.

Similar results were also obtained by Ibrahim \& Rebello (2012); Arends (2012); and Adeyemo (2010). Ibrahim \& Rebello (2012) states that there is an increase in average cognitive logic thinking ability of students taught using the problem-based learning model. Therefore, by applying this model, students can acquire knowledge and skills more effectively, as supported by Arends (2012) who states that a problem-based approach to learning in which students work on authentic problems with a view to drawing up their own knowledge, while the teacher acts as a facilitator requires that students be persistent in solving the problems presented. $\mathrm{He}$ also states that during the problem-solving process, the problem of the character of the students themselves will be apparent so that students can develop self-reliance and confident in achieving logical thinking abilities. Adeyemo (2010) also states that there is an increase in cognitive ability among students who are positively affected when problem-solving tasks in physics are discussed. 
de Sousa et al. (2017) state that when using various multimedia combinations, the unique nature of social sciences can be addressed effectively. This result, as well as ours, inferred that there exist a difference in logical thinking ability between the two classes. this is because, learning using multimedia helps encourage students to be actively engaged in the process of thinking with regard to the material and link it to real situation (Erceg, Maru `si'C, \& Slǐsko, 2011). Thereby, they are encouraged to be able to remember and apply the knowledge in everyday life. In this case, students are not just passively accepting material from lecturer but also actively solve problems. Arends (2012) who states that a problem based learning approach to learning in which students work on authentic problems with a view to drawing up their own knowledge, while the teacher as a facilitator then students must be persistent in solving the problems presented, during the solve the problem of unwitting students, then all the characters themselves will appear that students can develop self-reliance , and confidence so that logical thinking ability can be achieved (Özreçberoğlu \& Çağanağa, 2018).

In contrast to interactive multimedia based learning given in the experiment class, teaching activities conducted in the control class failed to improved students' score $(p<.05)$. This shows that the method used in the control class was not effective in improving logical reasoning. This finding is also supported by Lawson (1978), who argues that certain learning approaches, such as lectures, are not effective in improving logical reasoning. Bello (2014) said that the experimental group exposed to the process skill instruction approach performed significant better to improve formal thinking ability than the control group expose to the traditional instruction. Erceg et al. (2011) stated in their work that the students were assigned to solve one part special issue to investigate their problem-solving strategies. Lawson (1978) showed that students' score in 'Lawson classroom test of formal reasoning was correlated with their achievement in school subjects i.e. social studies, science and mathematics. this finding has provided concrete evidence that formal reasoning abilities can be related to students' general performance, not only to science and mathematics. Subali, Rusdiana, \& Sabandar (2013) said that descriptively the most MPK-GI group (empowerment conceptual model empowerment) excel in achieving critical thinking skills.

The results showed, to answer the question of physics, students must use the laws of physics to calculate the requested physical quantity, in accordance with the steps to solve the problem. They also have to calculate the quantity of answers from physics problems in everyday conditions. Tasks like these can help different concepts and techniques of problem solving are accepted, and train students and teachers to solve problems in everyday life using physical principles and assumptions.

In conclusion, learning media in the form of interactive multimedia tools is reasonably capable of providing learning experiences that correspond to the level of cognitive development of students. Barsalo (2014) classifies learning experience of children ranging from things that most concrete up to things that are considered the most abstract. The classification of such experiences is widely followed by the educational circles in deciding what tools should be appropriate to the particular learning experience (Mukherjee, 2013. One of them is interactive multimedia to enhance learning motivation and learning students who have lost interest in the course, may be because of the abstract nature of the subject (Adeyemo, 2010; Siddiquah \& Salim (2017) said that students spend more time on computers for recreational and other purposes than for academic purpose (Çakıroğlu \& Yilmaz, 2017; Kainz, Jakab, \& Kardos, 2013; Adlim, Nuzulia, \& Nurmaliah, 2018). They believe that the use of information and communication technology (ICT) supports their learning our results provide proof that is indeed an effective mode students' thinking. Masino \& Niño-Zarazúa (2016) stated that our findings suggest that interventions are more effective at improving student performance and learning when social norms and intertemporal choices are factored in the design of education policies, and when two or more drivers of change are combined. Argumentation is thinking ability that can occur in students who carry out discussions and debates to solve assigned problems. Building knowledge based on epistemic aspects requires a dialogical approach with evaluation of evidence and rational reasons in scientific ideas. 


\section{CONCLUSION}

In conclusion, learning media in the form of interactive multimedia tools is reasonably capable of providing learning experiences that correspond to the level of cognitive development of students. Edgar Dale classifies learning experience of children ranging from things that most concrete up to things that are considered the most abstract. The classification of such experiences is widely followed by the educational circles in deciding what tools should be appropriate to the particular learning experience (Arsyad, 2018), one of them is interactive multimedia to enhance students' skills in generic science class (Cronje \& Fouche, 2008). Our results provide proof that is indeed an effective mode students' thinking.

\section{ACKNOWLEDGMENT}

The research is funded by the competitive grants DP2M Director General of Higher Education Ministry of Education and Culture.

\section{REFERENCES}

Abungu, H. E., Okere, M. I. O., \& Wachanga, S. W. (2014). The effect of science process skills teaching approach on secondary school students' achievement in Chemistry in Nyando District, Kenya. Journal of Educational and Social Research, 4(6), 359-371. doi:10.5901/ jesr.2014.v4n6p359.

Adeyemo, S. A. (2010). Students' ability level and their competence in problem-solving task in Physics. International Journal of Education Research and Technology, l(2), 35-47. http://www.soeagra.com/ ijert/vol2/7.pdf.

Adlim, M., Nuzulia, R., \& Nurmaliah, C. (2018). The effect of conventional laboratory practical manuals on pre-service teachers' integrated science process skills. Turkish Science Education, 15(4), 116-129. doi:10.12973/tused.10250a.

Arends, R. I. (2012). Learning to teach $\left(9^{\text {th }} \mathrm{ed}\right)$. New York, NY: Mcgraw Hill.

Arsyad, S. (2018, 19-20 October). Struggling for international publication: The potential rhetorical problems for Indonesian scholars in social sciences and humanities when writing. Paper presented at Seventh International Conference on Languages and Arts (ICLA 2018), Padang, Indonesia. doi:10.2991/icla-18.2019.77.

Bello, A. (2014). The acquisition of the six formal reasoning abilities by students in Kaduna State, Nigeria. International Journal of Education and Research, 2(6), 613-628. https://www.ijern.com/journal/ June-2014/51.pdf.

Bimba, A., Idris, N., Mahmud, R., Abdullah, R., Abdul-Rahman, S-S., \& Bong, C. H. (2013). Problem representation for understanding physics problem. Research Notes in Information Science (RNIS), 14(June), 621-625. doi:10.4156/rnis. vol14.111.

Byun, J. N., Kwon, D. Y., \& Lee, W. G. (2014). Development of ill-structured problems for elementary learners to learn by computer-based modeling tools. International Journal of Computer Theory and Engineering, 6(4), 292-295. doi:10.1371/journal.pone.0095277.

Çakıroğlu, U., \& Yilmaz, H. (2017). Using videos and $3 \mathrm{D}$ animations for conceptual learning in basic computer units. Contemporary Educational Technology, 8(4), 390-405. doi:10.30935/cedtech/6207.

Chetty, R. (2015). Teaching teachers to teach Physics to high school learners. Procedia-Social and Behavioral Sciences, 174(2015), 1886-1899. doi:10.1016/j. sbspro.2015.01.852.

Cronje, J. S., \& Fouche, J. (2008). Alternatives in evaluating multimedia in secondary school science teaching. Computers \& Education, 51(2), 559-583. doi:10.1016/j. compedu.2007.06.012.

Cunningham, D. (2009, 8-10 October). Using ill-structured problems to develop metacognitive strategies. Paper presented at Annual Conference of The International Society for Exploring Teaching and Learning, Philadelphia, Pennsylvania. https://www.isetl.org/. 
Depdiknas. (2010). Paradigma pendidikan nasional Abad XXI. [The XXI Century national education paradigm]. Jakarta: BSNP.

De Sousa, L., Richter, B. W., \& Nel, C. (2017). The effect of multimedia use on the teaching and learning of social sciences at tertiary level: A case study. Yesterday and Today, 7(July), 1-22. doi:10.17159/22230386/2017/n17a1.

Erceg, N., Maru`si'C. M., \& Sli`sko, J. (2011). Students' strategies for solving partially specified physics problems. Revista Mexicana De F'isica E, 57(1), 44-50. http://www.scielo.org.mx/pdf/rmfe/ v57n1/v57n1a8.pdf.

Fenelon, O., \& Breslin, C. (2012). Chrime scene investigation in a lab: A problem solving approach to undergraduate Chemistry practical. Aishe-Journal, 1(1), 1-11. http:// ojs.aishe.org/index.php/aishe-j/article/ view/00071

Fhaeizdhyall, A., Nazamud-Din, A., Sabbir, F., \& Ibrahim, S. (2018). The effectiveness of teacher education program: Identifying the difficulties and challenges faced by the pre-service English teachers. International Journal of English Language Teaching, 6(1), pp.1-17. https://www. eajournals.org/journals/internationaljournal-of-english-language-teachingijelt/vol-6-issue-1-january-2018/ effectiveness-teacher-education-programidentifying-difficulties-challenges-facedpre-service-english-teachers/.

Fraenkel, J. R., Wallen, N. E., \& Hyun, H. H. (2012). How to design and evaluate reseource in education $\left(8^{\text {th }}\right.$ ed). New York, NY: McGraw Hill Company.

Gorghiu, G., Drăghicescu, L. M., Cristea, S., Petrescu, A-M., \& Gorghiu, L. M. (2015). Problem-based learning: An efficient learning strategy in the science lessons context. Procedia-Social and Behavioral Sciences, 191(June), 1865-1870. doi:10.1016/j.sbspro.2015.04.570.

Habibi, Z., \& Habibi, A. (2014). The effect of information technology in teaching Physics courses. The Eurasia Proceedings of Educational \& Social Sciences (EPESS), I (Eylül 2014), 391-396. https://dergipark. org.tr/tr/pub/epess/issue/30314/333442.

Halliday, D., Resnick, R., \& Walker, J. (2011). Fundamental of physics $\left(10^{\text {th }}\right.$ ed). Singapore: John Wiley \& Sons, Ptc Ltd.

Heller, K., \& Heller, P. (2010). Cooperative problem solving in Physics a user's manual. https://www.yumpu.com/en/ document/view/50363569/cooperativeproblem-solving-in-physics-a-usersmanual.

Ibrahim, B., \& Rebello, N. S. (2012). Representational task formats and problem solving strategies in kinematics and work. Physical Review Special Topics: Physics Education Research, 8(1), 0101261-01012619. doi: 10.1103/ PhysRevSTPER.8.010126.

Islam, Md. B., Ahmed, A., Islam, Md. K., \& Shamsuddin, A. K. (2014). Child education through animation: An experimental study. International Journal of Computer Graphics \& Animation (IJCGA), 4(4), 4352. doi: 10.5121/ijcga.2014.4404.

Kainz, O., Jakab, F., \& Kardos, S. (2013, 2425 October). The computer animation in education. In 2013 IEEE International Conference on Emerging eLearning Technologies and Applications. Stara Lesna, Slovakia: IEEE, pp. 201-206. doi:10.1109/ICETA.2013.6674428.

Kapi, A. Y., Osman, N., Ramli, R. Z., \& Taib, J. M. (2018). Multimedia education tools for effective teaching and learning. Journal of Telecommunication, Electronic and Computer Engineering, 9(2-8), 143-146. https://journal.utem.edu.my/index.php/ jtec/article/view/2645.

Kharida, L. A., Rusilowati, A., \& Pratiknyo, K. (2009). Penerapan model pembelajaran berbasis masalah untuk peningkatan hasil belajar siswa pada pokok bahasan elastisitas bahan. [Application of problem based learning models to improve student 
learning outcomes on the subject of material elasticity]. Jurnal Pendidikan Fisika Indonesia, 5(2009), 83-89. doi:10.15294/jpfi.v5i2.1015.

Lawson, A. E. (1978). The development and validation of a classroom test of formal reasoning. Journal of Research in Science Teaching, 15(1), 11-24. doi:10.1002/ tea.3660150103.

Manurung, S. R. (2014, 5-6 December). Contribution of formal thinking ability on the concept mastery of kinematics. Paper presented at The First International Seminar on Trends in Science and Science Education 2014, Universitas Negeri Medan, Indonesia.

Masino, S., \& Niño-Zarazúa, M. (2016). What works to improve the quality of student learning in developing countries? International Journal of Educational Development. 48(May), 53-65. doi:10.1016/j.ijedudev.2015.11.012.

Nickel, C. (2014). Rand spiro-cognitive flexibility theory (Unpublished Paper, Department of Educational Psychology, Michigan State University, Michigan).

Özreçberoğlu, N., \& Çağanağa, Ç. K. (2018). Making it count: Strategies for improving problem-solving skills in mathematics for students and teachers' classroom management. Eurasia Journal of Mathematics, Science and Technology Education, 14(4), 1253-1261. doi:10.29333/Ejmste/82536.

Piaget, J. (1964). The development of thought: The equilibrtion of cognitive structures.
New York, NY: Viking.

Subali, E., Rusdiana, D., \& Sabandar, J. (2013, 19 October). Reflective thinking skills in prospective Physics teachers. Paper presented at International Seminar of Mathematics, Science, and Computer Science Education (MSCEIS), Bandung, Indonesia.

Siddiquah, A., \& Salim, Z. (2017). The ICT facilities, skills, usage, and the problems faced by the students of higher education. Eurasia Journal of Mathematics Science and Technology Education, 13(8), 49874994. doi:10.12973/eurasia.2017.00977.

Sudarman, S. (2007). Problem based learning: Suatu model pembelajaran untuk mengembangkan dan meningkatkan kemampuan memecahkan masalah. [Problem based learning: A learning model for developing and improving problem solving skills]. http://physicsmaster. orgfree.com/Artikel\%20\&\%20Jurnal/ Waw as an $\% 20$ Pendidikan/PBL $\% 20$ Model.pdf.

Tobin, K. G., \& Capie, W. (1982). Relationship between formal reasoning ability, loans of kontrol, academic engagement and integrated process skills achievement. Journal of Research in Science Teaching, 19(2), 113-121. doi:10.1002/ tea.3660190203.

Tobin, K. G., \& Capie, W. (1981). Development and validation of a group test of logikal thinking. Education and Psychologikal Measurement, 41(2), 413-424. doi:10.117 $7 / 001316448104100220$. 